\title{
ISSUES \& CHALLENGES OF APPLYING ISLAMIC BANKING IN ZANZIBAR: A WAY FORWARD
}

\author{
Mzee, Mzee Mustafa, ${ }^{1 *}$ Ahmad Azam Othman ${ }^{2}$ \\ 1 PhD Candidate, Ahmad Ibrahim Kulliyyah of Laws, International Islamic University Malaysia, Malaysia \\ Email: mzee.mzee@live.iium.edu.my \\ 2 Ahmad Ibrahim Kulliyyah of Laws, International Islamic University Malaysia, Malaysia \\ Email: aazam@iium.edu.my \\ * Corresponding Author
}

\section{Article Info:}

Article history:

Received date: 15.03.2020

Revised date: 26.03 .2020

Accepted date: 26.04 .2020

Published date: 10.06.2020

\section{To cite this document:}

Mustafa, M. M., \& Othman, A. A. (2020). Issues \& Challenges of Applying Islamic Banking in Zanzibar: A Way Forward. International Research of Shariah, Muamalat and Islam, 2 (4), 22-34.

DOI: $10.35631 /$ IRJSMI.24003.

\begin{abstract}
:
The operation of Islamic banking in Zanzibar started in 2011 to boost economic activities and meet the demand of its people. However, the introduction of Islamic banking was not followed by any legal amendment to suit the operation of Islamic banking in the country as per Islamic principles. This paper, therefore, examines different laws which governed the Islamic banking in Zanzibar to find how far they support the operation of Islamic banking. The findings of this paper revealed that some of the laws in Zanzibar contain provisions that do not support Islamic banking transactions. The methodology adopted in this paper is based on the content analysis of legislations, leading textbooks, and journal articles. The study used a comparative method to address the study in question. The study recommends amendment of some laws such as the Contract Decree, 1917 and Transfer of Property Decree, 1917, Stamp Duty Act 2017, and Value Added Tax Act, 1998 for improving the legal regime governing Islamic banking transactions in Zanzibar.
\end{abstract}

Keywords:

Zanzibar, Islamic Banking, Fraud, sale, Murabahah, Musharakah, Ijarah

\section{Introduction}

Islamic banking is growing very fast in terms of services and products. Presently, Islamic banking is recognized all around the world because of its contribution to the world economy (Jamel \& Moussa, 2018). In Africa, especially in southern Africa, Islamic banking started in 1989 when Al Baraka Bank was established in South Africa (Kholvadia, 2017). Since then, many African countries incorporate Islamic banking to be part of their banking system. It was argued that Islamic banking is expected to boost sustainable development by facilitating economic growth activities in Africa through increasing international investment flows (Marcegaglia, 2017. In East Africa, Islamic banking is also growing rapidly starting from Copyright (C) GLOBAL ACADEMIC EXCELLENCE (M) SDN BHD - All rights reserved 
Kenya in 2005 when Barclays Bank and Kenya Commercial Bank opened the Islamic banking window (Kasule, 2019). The United Republic of Tanzania for the first time introduced Islamic banking in the country in 2007 through the meeting of the Board of Directors of Bank of Tanzania (Hikmany \& Oseni,2016). Consequently, in 2008, Kenya Commercial Bank (KCB) introduced Islamic banking products by introducing Amana account. It can be argued that the reason for the introduction of Islamic banking is associated with the demands of Muslims to have free interest banking serving them since interest is prohibited in Islam. It is pertinent to mention that, there is a slight development for Islamic banking since its introduction in 2007. To start with the Bank of Tanzania, the bank has received technical assistance from the International Monetary Fund (IMF) and East AFRITAC on developing a legal and regulatory framework for Islamic banking and also became a member of Islamic Financial Services Board (IFSB). Moreover, different universities have introduced Islamic banking courses to ensure the availability of human resource in this industry, some of the Non-Government Organizations were established to promote Islamic finance, for instance, the Center for Islamic Finance, Compliance and Advice (CIFCA) and different international conferences on Islamic finances were conducted, for instance, African Islamic Finance Summit. However, as most of the Commonwealth countries, the introduction of Islamic banking in Tanzania is accompanied with some challenges which need to be articulated. One of the key challenges of Islamic banking in Tanzania is lacking legal support for Islamic banking transactions, since Islamic banking was introduced without regard to the changing of domestic law to allow a smooth application of Islamic banking (IMF, 2017). Zanzibar being part of the United Republic of Tanzania with some of the internal autonomy benefited with this introduction of Islamic banking, since the banking business is within the union matters (Constitution of the United Republic of Tanzania, 1977). On the other hand, article 114 of the Constitution of the United Republic of Tanzania gives Zanzibar autonomy to do its internal affairs such as law-making for non- union matters through the House of Representatives. Among the laws which House of Representatives can make include those laws which govern contractual transactions, the formation of the business organization, land issues and taxes. Therefore, this study intends to indicate the areas of discrepancies between Zanzibar laws and Islamic banking principles.

\section{The Practice of Islamic Banking Transactions in Zanzibar}

Islamic banking in Zanzibar for the first time was introduced in 2011 when the People Bank of Zanzibar established the Islamic banking window (Soud \& Sayılır, 2017). Since then some commercial banks such as Kenya Commercial Bank, National Bank of Commerce and Amana Bank extended their Islamic banking products in Zanzibar. Thus, currently, there are four Islamic banks in Zanzibar. These are Amana Bank which operates as full-fledged, Kenya Commercial Bank (Sahl), National Bank of Commerce and People's Bank of Zanzibar which all operate through the window model. There are various financing products which these banks offer such as, Murabahah financing, Musharakah financing and Ijarah Mawsufah fi alDhimmah (forward lease) financing (Salim, 2016).

\section{Murabahah Financing}

Murabahah is a kind of sale where the seller expressly mentions the cost of the sold commodity he has incurred and sells it to another person by adding some profit thereon (Mayanja, 2016). Murabahah in Islamic banking is a kind of sale where the bank purchased a commodity on behalf of the customer from a third party and resells it to the customer on a cost-plus profit basis by expressly mentions the cost and profit to the customer (Mohd \& Abdallah, 2019). In Zanzibar, Murabahah financing is used to finance different products such as plant, machinery and equipment, car, surveyed plot, raw and building materials. The practice of Murabahah financing starts with a customer to find a property and its price than he applies to the bank for 
financing the transaction. Before the bank finances the transaction, the customer must meet the bank's requirements such as a letter of guarantee from an employer or security of immovable property. This requirement is made to ensure the customer repays the purchased price as agreed with the bank. However, for plot financing, the customer is not required to provide any kind of security instead he must contribute twenty percent of the purchased price. Having complied with those requirements, the bank mentions its profit to the customer for financing the transaction. Then, the bank purchases the property from the supplier and resells it to the customer who pays the purchased price in instalments for one or five years depends on the nature of the products (Mohd \& Abdallah, 2019). However, there are some customers who abuse this mode of financing. For instance, some customers syndicate with the suppliers by pretending that they need to purchase the goods from them and apply Murabahah financing from an Islamic bank, but in the real sense, they only need cash. Thus, once when the suppliers paid by the bank, they give the said money to the customers and retain their goods without transferring it to the bank or customer. This problem to some extent is also perpetuated by the Islamic banks themselves since in most cases they do not acquire the ownership of the goods from the supplier as required under the Murabahah financing contract. On the contrary, a supplier transfers the goods directly to the customer hence the bank acts as financer only and not the owner. Therefore, to minimise this problem it is recommended that the Islamic banks must first acquire the ownership of the goods from the supplier and then transferred it to the customer.

\section{Musharakah Financing}

Musharakah is a partnership contract between two parties to contribute towards the capital of commercial enterprise and share the accruing profits based on a format agreed upon when contracting the partnership and bear the loss jointly (Mayanja, 2016). In Islamic banking, Musharakah is used to finance different products such as projects, working capital and houses. However, the use of Musharakah in Zanzibar is mainly on Musharakah Mutanaqissah (Diminishing Musharakah) for house financing. A Musharakah Mutanaqisah or diminishing Musharakah is a partnership contract in which one partner undertakes to buy the whole shares of another partner gradually until he acquires a full ownership of the title (Asni \&Sulong, 2019). Thus, this contract consists of three contract; partnership, lease and sale. In Islamic banking, the diminishing Musharakah is used by banks for house financing. In this financing, the bank and customer participate in business venture on condition that the bank will recapture its initial investment along with its agreed share in the profit within an agreed time and a customer promises at the time of contract to purchase the share of the bank gradually to become a sole owner of the product (Mayanja, 2016). In Zanzibar, diminishing Musharakah for house financing is a contract that a bank and a customer jointly purchase a house. Hence, the customer's share increases gradually in the house by paying instalments until he secured the full ownership of the house. This transaction has the following stages; first, a customer has to find a house of his choice and its price then he can apply to the bank for financing the transaction. However, before bank agrees to finance, the customer must meet some banks' requirements such as he must contribute twenty percent of the purchasing price, he must provide a letter of guarantee from his employer, he should not exceed 45 years since by the time the contract is ending his age should not be more than 60 years which is a compulsory retirement age in Zanzibar (Ahmed \& Wang, 2018). Having complied with those conditions a bank and a customer jointly purchase and co-own a house. However, to ensure the customer pays the monthly instalments the house is registered as security until the customer completes purchasing bank's shares. Thereafter, the customer has to pay monthly instalments which include purchasing shares of the bank and rents for fifteen years. By doing that, the shares of the customer increase and shares of the bank diminish. Finally, the customer becomes the sole 
owner of the house. By considering this practice, it is submitted that the requirement of advancing twenty percent of the purchase price is high compares to the price of the houses and income of people of Zanzibar whose income per capita does not exceed TZS 2,323,000 (USD 1,026) (Abdiwawa, 2019). This situation for some extent obstructs most of the people to apply for house financing even though they are really in need of the houses. Thus, it is recommended that the reduction of twenty percent to five percent so as more people could apply for house financing.

\section{Ijarah}

Ijarah is a contract of a lease that contains the transfer of usufruct in exchange for consideration as a rental for a specifically determined time (Billah, 2019). In Zanzibar, most of the Islamic banks prefer Ijarah al-A'mal (service lease) particularly for Ijarah Mawsufah fi Dhimmah (forward lease) for financing education and financing pilgrimage (Hajj). To conclude this transaction, a customer is required to select a service that he needs within the list of service providers, which recognized by the given bank. Having done so, the customer is required to meet the conditions of the bank for financing the services. This includes having an account to the respected bank, tendering a letter of guarantee from his employer or security of the immovable property. Then, Islamic banking hires such service and pays for it. In return, the customer is required to pay the agreed payment for such services to the bank through installments for the agreed period. Since the focus of Ijarah based financing is Ijarah Mawsufah fi Dhimmah, it is therefore proposed that Islamic banks in Zanzibar should also consider offering Ijarah Thumma al Bay to finance different assets or equipment such as a car, a tractor, a boat, and other movable assets. By doing that, many people will have the opportunity to acquire those assets which can be used for economic activities to eradicate poverty among them. The application of Ijarah Thumma al Bay allows the customer to hire assets or equipment from the bank for agreed times, in return the customer pays the monthly rental to the bank. Having completed the payment, the ownership of the asset is transferred to the customer through sale contract. In Zanzibar, Ijarah Thumma al Bay is supported by the Financial Leasing Act, No. 5 of 2008 which was passed by the Parliament of the United Republic of Tanzania which also applicable in Zanzibar (Erogbogbo et al, 2013). Section 4(1) of this act defines the financial lease as an agreement between two parties in which the lessor in exchange for periodic payment of money leases an asset to the lessee for business purposes. However, section 4(7) provides that after the expiration of the lease agreement the lessee can purchase the asset after obtaining the consent of the lessor or returning the asset. Thus, it is argued that the application of Ijarah Thumma al Bay has also legal support this means it can be easily implemented by Islamic banks in Zanzibar.

\section{Challenges of Governing Laws for Islamic Banking Transactions in Zanzibar}

Article 106(3) of the Constitution of the United Republic of Tanzania of 1977 and article 99 of the Constitution of Zanzibar, 1984 empower Zanzibar to legislate laws for all matters which do not fall under the union matters (Katundu \& Kumburu,2015). Since there is no special law for Islamic banking transactions in Zanzibar, the same laws which apply in other transactions are also applicable for Islamic banking. These laws include Contract Decree, 1917, Registered Land Act, 1990, Transfer of Property Decree, 1917, Value Added Tax Act, 1998 and Stamp Duty Act, 2017. The application of these laws for Islamic banking has some legal challenges such as lack of lawful cause, non-disclosure of material defect, sale of the mortgaged property without the consent of the mortgagor and double taxation. 


\section{Lawful Cause}

To constitute a valid contract, the Contract Decree requires the objective of the agreement to be lawful. The law defines the term lawful to mean anything which is not forbidden by law, does not defeat the provisions of any law, not fraudulent, not an injury to property or person and not immoral or against public policy (Contract Decree, 1917 s. 23 (1)). The effect of this provision is that, if any party to the contract is aggrieved in an unlawful contract, he cannot recover his right. For instance, in Zakaria Barie Bura v. Theresia Maria John Mubiru (1995) TLR 211, the seller and purchaser prepared and signed two sale agreements, one of which shown a lesser sale price in order to defraud revenue authority. Among the issue before the Court of Appeal was whether the sale agreement had any legal effect. The Court of Appeal of Tanzania held that the making of the two agreement with the intention to defraud revenue authority was illegal agreement and void abinitio and unenforceable. Also, in Asha Soud Salim v. Tanzania Housing Bank (1983) TLR 270, the appellant's mother agreed with the predecessor of the respondent in 1959 to take a loan of shilling 45,000 to be repayable for twenty years with interest. After the death of her mother 1967, the appellant wished to continue with the agreement but on condition that she will pay outstanding principal sum plus interest up to 1964, when the Revolutionary Government of Zanzibar prohibited charging of interest. However, the respondent insisted that the appellant must pay full interest as provided in the agreement. Hence, the court must determine whether the contract was void for being illegal and against public policy. The Court of Appeal held that the contract was void due to the government proclamation which prohibited payment of interest and against public policy. Hence the appellant should not be found in fault of paying the interest. These cases support the legal requirement that any contract which against the law or public policy is unlawful. However, from the above discussion one can find that the law is silent on the cause of the agreement or motive which is intended to be achieved in the contract that to be also lawful. This is contrary to some of the Muslim's juristic opinion who viewed that contracting parties must ascertain whether the cause of the contract (sabab) is lawful or not, since if the cause of the contract is unlawful such a contract becomes void (Billah, 2016). It is important to note that, all Muslim jurists have agreed that a contract for an unlawful purpose is void (Saleh, 1992). However, their differences emerged into the motives or intention ( $s a b a b)$ of the contracting parties. For instance, Hanafi opined that if the intention of the contract is unlawful such a contract becomes reprehensible (makruh) and not void. A similar position was made with Shafi'i, but he added that the contract will be void if parties expressly agreed on that (Al-Shafi'i, 1973). On the other hand, Maliki and Hanbali both agreed that the result of legal action depends on the intention of the parties, thus if the intention of the contract is unlawful such a contract becomes null and void (Rosly \& Sanusi, 2001). Therefore, it is important for Islamic banking to ensure that the cause of the contract made with their customer is also lawful to make the transaction valid. For instance, if someone enters into a contract with the Islamic bank to buy a car through Murabahah financing, but he intends to use that car for carrying alcohol. This contract is not valid because the carrying of alcohol is prohibited in Islam (Al-Maidah: 90-91). Another example is a contract to acquire a house through diminishing Musharakah. If the customer intends to acquire the house from Islamic bank for a certain use which is prohibited in Islam such as making it as a night club or a bar club. This contract is not valid in Islam, because it involves prohibited things under Islamic law (Al-Isra: 32). Similarly, in Ijarah Mawsufah fi Dhimmah (forward lease) for education financing, if a customer requests it intending to undertake courses that involved prohibited things such as food and beverage which most of the time include alcohol, this contract is not valid in Islam. The problem with the underlying examples is that the objectives of those contracts above are lawful in Zanzibar since they are not forbidden by law, not defeat the provisions of any law, not fraudulent, not injury property or person or against public policy. Thus, an Islamic bank cannot repudiate those contracts if it 
finds out the causes of those contracts, though in Islamic law those contracts are unlawful for involving prohibited things. From the above discussion, the absence of a provision that invalidates a contract if its purpose is against Islamic law may make Islamic banking to be involved into a prohibited contract under Islamic law. Therefore, there is a need for Contract Decree to include a provision that covers the cause of contract to comply with Islamic principles.

\section{Non-Disclosure of Material Defect}

The law governing contractual relationship in Zanzibar requires a contract to be concluded with a free consent (Contract Decree, 1917 s. 10). Thus, to constitute a free consent the contract should not be concluded with the presence of some elements such as fraud or mistake. If the contract concluded with those elements the contract becomes voidable or void because it lacks a free consent (Contract Decree, 1917 s. 19(1), 21(1)). The Contract Decree defines a fraud as any of the following acts committed by a party to a contract or his agents, with intent to deceive another party thereto or his agent, or to induce him to enter into the contract. These acts include the suggestion as a fact, of that which is not true, by one who does not believe it to be true; the active concealment of a fact by one having knowledge or belief of the fact; promise made without any intention of performing it; any other act fitted to deceive; any such act or omission as the law specially declares to be fraudulent (Contract Decree, 1917 s. 17(1) a-e). However, the same provision excludes silence to the fact as a fraud unless if it is the duty of a person to speak. This provision gives opportunity to a seller or service provider not to disclose any defect to the goods or service which he provides (Abdul Rahman, 2018). Thus, if a buyer or a service beneficiary finds such defect to the goods or service, he cannot annul the contract since the silence of buyer or service provider was not constituted a fraud. For instance, in Abdulla Ali Nathoo v Walji Hirji, (1957) 1 EA 207 (HCZ), the court applied this provision to deny a right to repudiate a contract of sale after an agent failed to examine the bad goods before sale. On the other hand, the law provides if both parties to an agreement are under a mistake to the matter of fact which essential to the agreement such agreement becomes void (Contract Decree, 1917 s.21). However, if the mistake was caused by one party to the agreement, such a contract cannot be avoided (Contract Decree, 1917 s.22), unless if the aggrieved party successfully proves the doctrine of non est factum. This was also stated in Tanganyika Bus Service Co. Ltd v. The National Bus Service Ltd (KAMATA) (1986) TLR 203, where the court held that a unilateral mistake by one party to the contract will affect the validity of the contract only if the doctrine of non est factum is successfully proven. However, to prove that is not a simple task, for instance, Lord Reid in Saunders v Anglia Building Society (1970) 3 All E.R. 961 provides that to prove the doctrine of non est factum a person must show that he suffered from a disability such as blindness or illiteracy that he could not understand the nature of the transaction. Having discussed the position of law in Zanzibar it is important also to note that, under Islamic law the concept of free consent is also emphasized and goes beyond the parameters of the Contract Decree. For instance, in the Quran Allah says, "O you who believed! Eat not up to your property among yourselves unjustly, except that it's trading by a mutual consent" (An-Nisai: 29). This verse shows that, if any party obtains the consent of another person through fraud or mistake the contract becomes invalid subject to be rectified by the aggrieved person (Khiyar Al- 'Ayb) (Karim\& Sifat, 2018). In addition, the Prophet (s.a.w) has reported saying that "whenever you enter into a contract say to another party that there shall be no fraud and I reserve my right of an option in three days" (Sahih Muslim). These authorities show that, it is a fundamental principle in Islamic law that a contract must be concluded with a mutual consent otherwise the contract becomes invalid. Thus, to ensure contracting parties are not involved in fraudulent acts Islamic law requires a seller to disclose to a buyer any material defect to the goods which he sells to him. Failure to disclose such defect is regarded as a great sin, this was provided in 
Prophetic tradition when the Prophet Muhammad (s.a.w) said: "Whosoever sells a defective product without disclosing its defect to the purchaser, shall earn the permanent anger of Almighty Allah and the angels continuously curse such a person" (Sunan Ibn Majah). In Islamic jurisprudence, there is no unanimous opinion on what constitutes a material defect. For instance, Imam Hanafi and Hanbali opined that material defects are anything that results in the diminution of value as per commercial custom, but Imam Malik viewed that the material defect is anything that renders a price of goods to be reduced. Imam Shafii considered a material defect as anything which affects a buyer's legal aims not to be accomplished (Syihab, 2016). From these opinions it seems that Imam Shafii's view is more practicable for Islamic banking since it provides that if the purpose of financing is not accomplished due to fraud the contract should not be valid. On the other hand, if a person finds a defect to the property, he may rescind the contract. However, it is important to note that, while all Muslim scholars agreed on the applicability of optional right, there are different juristic opinions on when does an aggrieved party can rescind the contract. For instance, Imam Abu Hanifa and Shafie viewed that contracting parties have three days to exercise the optional right, but Imam Malik opines that the period must be determined with the customs and usage of trade in a locality (Dahlan, 2014). On the contrary, Imam Hanbali viewed that the limitation period to exercise optional rights must be determined with the contracting parties themselves. By looking into these opinions, one can agree that the opinion of Imam Hanbali is more practicable and useful for Islamic banking transactions since it gives parties the right to decide themselves when the limit should end.

Therefore, goes back to the governing law, one can find that the concept of a free consent as enshrined in the Contract Decree to some extent contradicts with Islamic law in two ways. First, by looking into the definition of the fraud, one can find that the law exempts a mere silence on the part of one party to the contract as a reason to repudiate a contract. This means that the law requires parties to the contract to use reasonable care before making the contract. The effect of this provision is that in case of defect the aggrieved party may not have a chance to repudiate the contract. This principle is contrary to the Islamic law which imposes a duty to the seller to caution and notifies the purchaser on the defect of the goods before the sale. For instance, under Murabahah contract a supplier can know that the car has a defect but yet does not mention it to the buyer. Similarly, under diminishing Musharakah, a house may also contain some defects which known only by the owner but does not disclose them to either bank or customer during contractual agreement. Hence, after concluding a sale the buyer cannot repudiate it since it does not fall under the definition of fraud. Similarly, in Ijarah Mawsufah fi Dhimmah (forward lease) for education financing, it is possible for educational institutions to provide education services without being registered or obtained accreditation from education authority, yet the institution does not mention it to the students. This example may not constitute a fraud as per Contract Decree while in Islamic law it may constitute a fraud since the institution fails to disclose this fact to the students. Therefore, there is a need for this law to impose a duty for the contracting parties such as the supplier of goods or services to disclose the defects to in that goods or service if he fails to do so the law should give an option for a buyer to take it or not. Second, the first provision of definition of mistake has no problem with Islamic law because it underlines both contracting parties to understand the nature of their agreement before concluding it. However, the second provision contradicts with Islamic law since it says if the mistake was caused by one party to the agreement, such a contract cannot be avoided, unless if the aggrieved party successfully proves the doctrine of non est factum (Contract Decree, 1917 s.22). The problem of this provision is that it repudiates a right to the aggrieved party to rescind a contract if he finds the defect to that contract. This is contrary to Islamic law which gives a contracting party a right to rescind the contract if he finds a defect 
to the goods (Sanusi, 2012). Therefore, there is a need for this provision to be amended to give an option to the aggrieved party who by mistake concluded a defective contract to rescind the contract when he finds the defect to the subject matter of the contract.

\section{Sale of Mortgage Property}

In Zanzibar the Transfer of Property Decree deals with the transfer of a property as security in the form of a mortgage (Hikmany et al, 2016). The law recognizes different kinds of mortgages such as simple mortgage, English mortgage and an anomalous mortgage. However, the practice shows that most of the banks in Zanzibar prefer to use anomalous mortgage which its rights and liabilities are determined with the mortgage deed (Transfer of Property Decree, $1917 \mathrm{~s}$. 87). This situation allows the banks to draft the mortgage deeds in their favor. For instance, among the common mortgage deed term is to give a bank a right to sell a mortgaged property in case of default to pay the loan by the mortgagor. This term to some extent is used by banks to sell the mortgaged property without obtaining the court's order. For instance, in Juma Jaffer Juma v. Manager of the Peoples' Bank of Zanzibar Ltd and Two Others (2004) TLR 332, the People's Bank of Zanzibar sold the appellant house which was mortgaged to secure an overdraft facility worth TZS. 1.5 million without obtaining the court's order. The bank then sold the house relied on clause 11 of the mortgage deed which stipulated that the bank has a right to sell a mortgaged property without complies with the restrictions provided under the Transfer of Property Decree, Chapter 150. Being unsatisfied with the sale of the house without court intervention, the appellant unsuccessful prayed to cancel the sale of the house in Regional court and High court. Hence, he appealed to the Court of Appeal which however upheld the decisions of the lower courts since the mortgage deed executed by the appellant and the bank was not a simple mortgage and therefore there was no need under the Mortgage Deed for the bank as mortgagee to cause the mortgaged property to be sold through court's intervention.

The concept of making a property as security for payment of money (Rahn) is commanded in the Quran if a person involved in a debt transaction to secure the debt (Al-Baqarah:282). The aim of Rahn is to protect the wellbeing of the debtor and the creditor for guarantee the settlement amount. However, some Muslims scholars such as Ibn Hazm Az-Zahiri have argued that the concept of Rahn is acceptable only if the parties are in the journey and they want to make debt transactions but they don't have a writer who can write on the transaction or they don't have two witnesses who can testify the transaction (Syairazi \& Rusni, 2018). However, the majority view of Muslim scholars supports Rahn since even the Prophet (s.a.w) pledged his iron armor in Medina to get food from the Jew (Sahih al- Bukhari). This shows that Rahn can be exercised anytime when someone needs something from another person regardless of the above conditions mentioned by Ibn Hazm Az-Zahiri. The main purpose of Rahn under Islamic law is to safeguard the interest of the creditor and makes a debtor pays his debt since his asset is under the possession of his creditor. Thus, it can be argued that the main function of the Rahn is to sell the property if the debtor fails to secure his debt so as the creditor can be repaid his money (Hussain \& Ali, 2017). Rahn can be for movable properties as a pledge or immovable properties as a mortgage depends on the nature of the agreement between creditor and debtor. However, it is important to ensure that a Rahn property must be one among the property that can be sold as per Islamic law and it is free from any encumbrance. Having discussed the position of Rahn in Islam it is important to note that, the process of selling a mortgaged property without the court involvement as provided in the Transfer of Property Decree for an anomalous mortgage is not accord with Islamic law. The majority views of Muslim scholars maintain that, the right to sell the secured property after default to pay the debt vested to the debtor (Mc Millen, 2015). However, if the debtor refuses to sell the property, the creditor must obtain the court's order to enforce the sale of the property (Ibrahim \& Salleh, 2006). This based on the fact that the creditor is just a trustee of the property and not the owner, hence a person cannot 
sell or transfer anything which he does not own (Gillat \& Jabareen, 2016). Therefore, to comply with Islamic law there is a need for the the law to be amended to ensure that a bank cannot sell the mortgaged house without first obtaining the consent of the customer or court's order. However, since it is impossible to acquire the consent after the defaults, it is recommended that a bank should obtain a customer prior consent during the process of making a contract by requesting a customer to delegate his power of sale a mortgaged property to the bank in case of any default to pay his debt.

\section{Double Taxation}

One among the duty of any government is to collect taxes from its citizens according to the law. For Islamic banking transactions in Zanzibar there are two laws that govern taxes administration these laws are the Value Added Tax Act, No. 4 of 1998 and Stamp Duty Act, No. 7 of 2017. The Value Added Tax Act requires charge of Value Added Tax (VAT) for any supply of goods or services and to be paid by a taxable person (Value Added Tax Act, 1998 s. 4(1) (2)). Also, the Stamp Duty Act requires imposition and collection of stamp duty on the supply of goods and services in Zanzibar (Stamp Duty Act, 2017 s. 3). Since the modus operandi of Islamic banking involves purchasing and selling of the goods and services these two laws are very important for the operation of Islamic banking transactions in Zanzibar. However, the current situation allows Islamic banking transactions to be taxed twice for the same transaction (Omar \& Yusoff, 2019). For instance, in Murabahah car facility a bank buys a car from the owner, this sale is charged stamp duty. Afterward, the same car is sold to the customer this transaction also charged another stamp duty (Stamp Duty Act, 2017 s. 20). Similarly, the Value Added Tax Act requires payment of 18 percent of the total price for any supply of goods or services (Value Added Tax Act, 1998 s. 8(1)). Therefore, due to the nature of Islamic banking transactions, one transaction can be charged VAT twice. The first VAT will be charged on purchasing of the car between a supplier and Islamic bank and second VAT will be charged on purchasing between Islamic bank as financier and customer as a buyer. The same example can be used for other Islamic banking financing products such as diminishing Musharakah for house financing or Ijarah (lease). The effect of double taxation makes the Islamic bank's products to be more expensive compared with conventional banking. This situation makes a hardship for Islamic banking to operate under the existing tax administration. Islam on many occasions has obliged the state and individuals to remove any kind of hardship to humankind. This was reported in the famous hadith which reported by Abu Sa'id al-Khudri, who said that the Messenger of Allah (saw) said: "it is not allowed to do harm nor to allow being harmed" (Ibn Majah). The word hardship which mentioned in this hadith includes an economic hardship. To remove economic hardship, Islam encourages payment of Zakat as a source of revenue of the Islamic state to help weak persons in the society to live in harmony without any sufferings (Ayuba, 2016). Payment of zakat occurs after someone meets some conditions prescribed by shariah this includes someone who must have a surplus to his basic needs before paying it. This is supported by Quranic injunction when Allah said: "they ask you what they should give, say give what you can spare" (Al-Baqarah:219). Base on this verse, the payment of any monetary obligation in Islam is required when someone has excess. Thus, the imposition of a monetary obligation to any person who has no enough money to satisfy his need is not acceptable since it creates financial hardship which is prohibited in Islam. In the same vein, Ibn Khaldun emphasized the payment of taxes on equity by considering the capacity of a person to pay without imposing hardship on him (Ibn Khaldun, 2015). Therefore, it is expected that the government when imposing taxes to its citizens to consider the capacity of its people in paying such taxes to protect weak persons from economic hardship. However, the experience shows that one among the things which provide hardship to the weak people is multiple taxes. The multiple taxes make weak persons not to afford even their basic needs like 
houses and other things. This situation has also affected Islamic banking which aims to protect weak persons from economic hardship due to the multiple taxes. Therefore, to give equal treatment with conventional banking, the government should amend the laws to allow Islamic banking transactions to be taxed once in stamp duty and VAT. Different countries have amended their taxes law to support Islamic banking. To mention a few; Kenya amended Stamp Duty Act and the Public Finance Management Act in 2017 to give tax neutrality to the Islamic banking business (Mwaniki,2017). The United Kingdom has amended Land Duty Stamp Act to remove double taxation in Islamic banking (Ercanbrack, 2015). Nigeria in 2013 issued a guideline that exempted Islamic banking and its financial institutions from being taxed twice (Federal Inland Revenue Service, 2013). In Malaysia, the Stamp Act, 1949 provides provisions which give a tax incentive for Islamic financing body such as Islamic banking. For instance, the Act charge duty only on the principal documents in case of several documents in Islamic banking (Ali et al, 2018). Also, the Act does not charge a tax on selling price instead of financing amount only. Zanzibar can follow the suit to remove hardship to its people.

\section{Conclusion}

It was observed that some of the principles of legislations which governed Islamic banking in Zanzibar are not compliant with Islamic banking principles. Hence, it is argued that there is a lack of legislative support for Islamic banking in Zanzibar. This situation if left unchecked and continue to exist will raise a dispute between Islamic law and existing laws. Consequently, the latter laws will prevail since the Shariah law is not applicable in contractual transactions. Hence, it will diminish the purpose of having Islamic banking in Zanzibar. Therefore, there is a need for the amendments of some legislations to ensure appropriate operation of the Islamic banking in Zanzibar. To start with the Contract Decree, 1917 the law should be amended to include a provision that shows a silent in contractual transaction constitutes a fraud. Also, the law should include a provision that gives an option to the aggrieved party who by mistake concluded a defective contract to rescind the contract when he finds the defect to the subject matter of the contract. Further, there is a need for the Transfer of Property Decree, 1917 to be amended to ensure that a bank cannot sell a mortgaged house without obtaining the consent of the customer or court's order. However, since it is impossible to acquire the consent after the defaults, it is recommended that a bank should obtain a customer's consent during the process of making a contract by requesting a customer to delegate his power of sale a mortgaged property to the bank in case of any default to pay his debt. Furthermore, to give equal treatment with conventional banking, the government should amend the Value Added Tax, 1998 and Stamp Duty Act, 2017 to allow Islamic banking transactions to be taxed once in stamp duty and VAT. Moreover, it is important for the Islamic banks when drafting contractual terms for their transactions with their customers to ensure that those terms cover Islamic legal principles. By doing that, these contractual terms will minimize the application of existing laws which some of them contain provisions which contradict with the Islamic legal principles.

\section{References}

Abdiwawa, A.M. (2019). Budget Speech of Ministry of Finance and Planning Financial Year 2019/2020. Ministry of Finance and Planning, Zanzibar.

Abdul Rahman, N. (2018). The Rise and Fall of Caveat Emptor in Malaysian Sale of Goods Contract. Journal of Law \& Governance, 1 (1), 1-14.

Ahmed, S. \& Wang, B. (2018). A Review on Retirement Practices Towards Public Employees in Zanzibar in Tanzania. American Scientific Research Journal for Engineering, Technology and Sciences, 42(1), 231-241.

Ali, S., Hasan, R. \& Othman, A. (2018). Legislative Intervention in Support of Islamic Banking in Malaysia. Malayan Law Journal, 4, xviii-xxxv. 
Al-Shafi'i, (1973). Kitab al-Umm. Beirut: Dar al-Marifa, Vol. 3.

Asni, F. \& Sulong, J. (2019). Analysis of the Development of Islamic Home Financing History in Malaysia. International Journal of Academic Research in Business and Social Sciences, 9(6), 817-828.

Ayuba, M. (2016) Islamic Economic System, Poverty and Insurgency: From Zakah Distribution to Capacity Building. International Journal of Islamic Economics and Finance Studies. 2(3), 53-72.

Bassem Ismail \& Hamidah. (2019). Financial Control Between Rashidun Caliphs and the Late $11^{\text {th }}$ Century. Journal of Islamic Studies, 9(1), 43-64.

Beatson, J., Burrows, A. \& Cartwright, J. (2016). Anson's Law of Contract" $30^{\text {th }}$ edition, Oxford: Oxford University Press.

Billah, M. (2016). Agency Contract under Conventional Law and Islamic Law as Manifested in the Civil Code of Oman: A Comparative Analysis. Electronic Journal of Islamic and Middle Eastern Law, 4, 109-126.

Billah, M. (2019). Modern Islamic Investment Management: Principles and Practices. Cham: Springer Nature AG.

Cartwright, J. (2009). Unilateral Mistake in the English Courts: Reasserting the Traditional Approach. Singapore Journal of Legal Studies, 226-234 at 227.

Constitution of the United Republic of Tanzania, 1977

Dahlan, N. (2014). Issues of Khiyar (Option) in Housing Agreements in Peninsular Malaysia. Malayan Law Journal, 1(1), 1-22.

Ercanbrack, J. (2015). The Transformation of Islamic Law in Global Financial Markets. Cambridge: Cambridge University Press.

Erogbogbo, V., Eghobamieni, E. \& Pimentel, E. (2013). Gender Responsive Investment Handbook: Addressing the Barriers to Financial Access for Women Enterprises. London: Commonwealth Secretariat.

Fumbo, C. \& Ziebertz, H. (2018). Judicial Rights among Youth in Tanzania. In Sterkens, C. \& Ziebertz, H. (Eds), Political and Judicial Rights through the Prism of Religious Belief (pp. 185-215). Cham: Springer International Publishing AG.

Ghai, Y. (2013). Zanzibar in Tanzania: From Sovereignty to Autonomy. In Ghai, Y. \& Winston, S. (Eds), Practising Self-Government: A Comparative Study of Autonomous Regions (pp. 258-280). New York: Cambridge University Press.

Hikmany, A. \& Oseni, U. (2016). Dispute Resolution in the Islamic Banking Industry of Tanzania: Learning from Other Jurisdictions. International Journal of Islamic and Middle Eastern Finance and Management, 9(1), 125-142.

Hikmany, A., Abdulkader, S. \& Othman, A. (2016). The Compatibility of Land Tenure Law in Zanzibar with Islamic Principles: An Analysis. IIUM Law Journal, 24 (1), 129-156.

Ibn Khuldun, (2015) Al Muqadimah, an Introduction to History. New Jersey: Princeton University Press.

Ibn Maja, A. (1999). Sunan Ibn Majah. Riyad: Darussalam Publishers.

Ifraq, T. (2014). Rahn Services Offered by Contemporary Islamic Financial Institutions: Challenges and Prospects. Pakistan Journal of Islamic Research, 14, 43-62.

Indrawan, A. \& Busthami, M. (2018). Adultery in the Perspective of Islamic Law and the Criminal Law Legislation a Comparative Study, Journal of Humanities and Social Science, 23(2), 51-55.

Israel, G. \& Amal, J. (2016). The Effect of Military Conquest on Private Ownership in Jewish and Islamic Law. Journal of Law and Religion, 31(2), 227-260.

Jamel, B. \& Moussa, F. (2018). The effect of Islamic Banks on GDP Growth: Some Evidence from Selected MENA Countries. Borsa Istanbul Review, 18(3), 231-247. 
John Cartwright (2009). Unilateral Mistake in the English Courts: Reasserting the Traditional Approach, Singapore Journal of Legal Studies, 226-234.

Karim, R. \& Sifat, I. (2018). Treatment of Silence as Misrepresentation in Contracts: A Critical Comparative Analysis of Common Law and Islamic Jurisprudence. International Journal of Law and Management, 60(1), 69-78.

Kasule, T. (2019). The History and Development of Islamic Economics and Finance in East Africa. IKAM Reports 9, Country Reports No. 4.

Katundu, M. \& Kumburu N. (2015). Tanzania's Constitutional Reform Predicament and the Survival of the Tanganyika and Zanzibar Union. The Journal of Pan African Studies, 8(3), 104-118.

Katundu, M. \& Kumburu, N. (2015). Tanzania's Constitutional Reform Predicament and the Survival of the Tanganyika and Zanzibar Union. The Journal of Pan African Studies, 8(3), 104-118.

Kholvadia, F. (2017). Islamic Banking in South Africa Form Over Substance? Meditari Accountancy Research, 25(1), 65-81.

Lakhi, M., Gul-e-Rana, I., \& Aziz, S. (2019). Maqasid Shariah, Islamic Financial Industry and Addressing the Concerns. Journal of Islamic Business and Management, 9(2), 368-376.

Lokmanulhakim, H. \& Ali, M. (2017). Shariah Non-Compliant Assets as Rahn (Pledge) in Islamic Banking Products: A Fiqhi Perspective, ISRA International Journal of Islamic Finance, 9(2), 196-199.

Marcegaglia, E. (2017). "En Creating Benefits for All Driving Inclusive Growth through Trade and Investment B20-Taskforce Trade \& Investment Policy Paper. B20 Taskforce Financing Growth \& Infrastructure Policy Paper. Retrieved from https://www.b20germany.org/priorities/financing-growth-infrastructure/fgirecommendations/

Mayanja, S. (2016). The Law of Islamic Banking and its Application in East Africa. Zanzibar: Sumait University Press.

Mc Millen, M. (2015). Implementing Shariah-Compliant Collateral Security: Select Issues. In Frederique, D. Research Handbook on Secured Financing in Commercial Transactions (pp. 97-131). Cheltenham: Edward Elgar Publishing Ltd.

Moh'd, F. \& Abdullah, R. (2019). Challenges on Cost Plus (Murabahah) Based Financing: Zanzibar Experience. European Exploratory Scientific Journal. 3(2), 1-16.

Nik Azman, H., Kassim, S. \& Adeyemi A. (2018) Analysing Ar-rahnu in the Context of Informal Credit Market Theory: Evidence from Women Micro-Entrepreneurs in Malaysia. ISRA International Journal of Islamic Finance, 10(2), 237-250.

Omar, H. \& Yusoff, M. (2019). Central Bank Impact on Practicing Mudarabah Financing in Islamic Banks: The Case of Tanzania. Banks and Bank Systems, 14(1), 81-93.

Oosthuizen, C. \& Song, I. (2014). Islamic Banking Regulation and Supervision: Survey Results and Challenges. IMF Working Paper No. 14/220 (2014), 7

Pradeep, K., \& Ali, Maulana. (2018). A Decade of Creating an Alternative Banking System in Tanzania: The Current State of Affairs of Islamic Banks. International Journal of Economics and Management Engineering, 12(10), 1271-1276.

Rosly, S. \& Sanusi, M. (2001). Some Issues of Bay' al-Inah in Malaysian Islamic Financial Markets. Arab Law Quarterly, 16(3), 263-280.

Saleh, N. (1992). Are the Validity and Construction of Legal Acts Affected by Cause (Sabab)? (A Comparative Study under Islamic and Arab Laws). Arab Law Quarterly, 7(2), 116140.

Sanusi, M. (2012). Islamic Banking and Finance Shariah \& Legal: Issues and Challenges. Selangor: ASLITA SDN. BHD. 
Soud, N. \& Ozlem S. (2017). Perceptions of Islamic Banking among Muslim and Non-Muslim Citizens in Tanzania. International Journal of Islamic Economics and Finance Studies, 3(3), 15-29.

Syairazi, M.H. \& Rusni Hassan. (2018) Comparing the Concept of Rahn and Debenture in Islamic Finance Perspective" e-Proceedings of the Global Conference on Islamic Economics and Finance 2018, 24 $4^{\text {th }}-25^{\text {th }}$ October 2018, Bank Negara Malaysia, Kuala Lumpur.

Syihab, F. (2016). The Doctrine of Khiyar Al-Ayb in Protecting the Customer's Rights. Akademika, IX, 75-88.

Uzaimah Ibrahim \& Safinar Salleh. (2006). The Objectives of Al-Rahn and their Achievement in Charge/Mortgage in Islamic Home Financing: An Analysis", Paper presented at the International Conference on Islamic Jurisprudence and the Challenges of the 21st Century: Maqasid al-Shariah and its Realization in Contemporary Society, 8-10th August 2006, IIUM.

Yassir Salim (2016), "Tapping the Potential of Islamic Finance in Retail Banking Industry in Tanzania" Retrieved from http://www.alhudacibe.com/roadshow2016/images/Tanzania-

Presentations/Tapping\%20the\%20Potential\%20of\%20islamic\%20Finance\%20in\%20 Retail\%20Banking\%20space\%20.ppt.

\section{Legislations}

Contract Decree, Cap 149 of 1917.

Federal Inland Revenue Service 2013 "Guidelines on Tax Implications of Non-Interest Banking in Nigeria

Financial Leasing Act, No. 5 of 2008

Stamp Duty Act, No. 7 of 2017

Registered Land Act, No. 10 of 1990

Transfer of Property Decree, Cap 150 of 1917

Value Added Tax Act, Act No. 4 of 1998 